OSTASH B.O. ${ }^{1}$, MISAKI Y. ${ }^{2}$, DOLYA B. ${ }^{1}$, KHARATON Y. ${ }^{1}$, BUSCHE T. ${ }^{3}$, LUZHETSKYY A. ${ }^{4}$, KALINOWSKI J. ${ }^{3}$, OCHI K. ${ }^{2}$, FEDORENKO V.O. ${ }^{1 凶}$

${ }^{1}$ Ivan Franko National University of Lviv,

Ukraine, 79005, Lviv, Hrushevskoho, 4

${ }^{2}$ Hiroshima Institute of Technology,

Japan, Saeki-ku, Hiroshima 731-5193

${ }^{3}$ Center for Biotechnology, Bielefeld University,

Germany, Bielefeld

${ }^{4}$ University of Saarland,

Germany, 66123, Saarbrbcken, University Campus, Building C2.3

凶iktor.fedorenko@lnu.edu.ua,+38(032) 239-44-07,+38(032) 239-44-75

\title{
GENERATION AND INITIAL CHARACTERIZATION OF A COLLECTION OF SPONTANEOUS STREPTOMYCES ALBUS J1074 MUTANTS RESISTANT TO RIFAMPICIN
}

\begin{abstract}
Aim. Streptomyces albus J1074 is one of the most popular streptomycete chassis for heterologous expression of natural product (NP) biosynthetic gene clusters (BGCs). There is keen interest in further improvement of the strain to provide increased yields of corresponding NPs. Introduction of certain types of antibiotic resistance mutations is a proven way to improve Streptomyces strains. For example, selection for increased resistance to rifampicin is known to lead to increased antibiotic activity. Here we used available lineages of antibiotic-resistant mutants of S. albus to raise rifampicin-resistant variants (Rifr) and to study their properties. Methods. Microbiological and molecular genetic approaches were combined to generate Rifr mutants and to study their properties. Results. By plating S. albus onto GYM agar supplemented with $10 \mathrm{mcg} / \mathrm{mL}$ of rifampicin, we isolated 85 stable Rifr colonies, whose resistance level was within $10-200 \mathrm{mcg} / \mathrm{mL}$ range. Sequencing revealed wide spectrum of missense mutations within rpoB gene. Bioassays demonstrated dramatically increased endogenous antibiotic activity of certain Rifr mutants. Conclusions. Selection for rifampicin resistance is a viable way to increase the yields of NPs in S. albus.
\end{abstract}

Keywords: Streptomyces albus J1074, antibiotic resistance, rifampicin.

Streptomyces albus J1074 (also known as $S$. albidoflavus J1074) is one of the most versatile and genetically amenable streptomycetes widely used for drug discovery purposes [1]. The range of applications includes heterologous expression of gene clusters and metagenomic libraries; incorporation of unnatural amino acids into ribosomally produced peptides; generation of whole-cell biosensor systems. NPs are produced by the wild type and heterologous streptomycete hosts in low yields, and this shortcoming pertains to $\mathrm{J} 1074$ as well. It prompts the interest in strain improvement investigations. Introduction of certain antibiotic resistance mutations into Streptomyces genomes has long been known to improve NP biosynthesis. Most of these mutations alter the function of ribosome (streptomycin, paromomycin, thiostrepton resistance) or $\beta$ subunit of RNA polymerase (RpoB; rifampicin resistance); the approaches based on these mutations were collectively referred to as ribosome engineering [2]. We recently developed a rational genome engineering method to introduce point mutations into the genes usually targeted by the ribosome engineering, e.g. $r p s L$ for $\mathrm{S} 12$ ribosomal protein [3]. This led to a collection of J1074 rpsL mutants with variable levels of activation of their indigenous secondary metabolism. The $\operatorname{rps} L$ mutant carrying R94G substitution turned out to be one of the most productive (A. Luzhetskyy, unpublished), prompting us to generate $S$. albus strain carrying this allele in merodiploid state (e.g. $r p s L$ and $r p s L^{\mathrm{R} 94 \mathrm{G}}$ alleles co-exist in $\mathrm{J} 1074$ chromosome; the latter was introduced on integrative actinophage VWB-based vector pTOS [4]). It is important to note that $\mathrm{R} 94 \mathrm{G}$ allele is one of those $\operatorname{rps} L$ mutations that do not lead to increased aminoglycoside resistance. As the accumulation of several different

\footnotetext{
${ }^{\circ}$ OSTASH B.O., MISAKI Y., DOLYA B., KHARATON Y., BUSCHE T., LUZHETSKYY A., KALINOWSKI J., OCHI K., FEDORENKO V.O.
} 
resistance mutations in single genome is known to provide further increases in NP titers [2], we used R94G strains as a starting point to generate strains resistant to streptomycin, lincomycin and erythromycin. As a result, we picked quadruple pure $r p s L$ mutant KO-1305 $\left(r p s L^{\mathrm{R} 94 \mathrm{G}} r s m G\left(\mathrm{Str}^{\mathrm{r}}\right)\right.$ Lin $^{\mathrm{r}}$ Ery $^{\mathrm{r}}$ ) and merodiploid mutant KO-1307 (rpsL $r p s L^{\mathrm{R} 94 \mathrm{G}} r s m G\left(\mathrm{Str}^{\mathrm{r}}\right) \mathrm{Lin}^{\mathrm{r}}$ Ery' $\left.{ }^{\mathrm{r}}\right)$. The aforementioned strains exhibited increased antibiotic activity against Staphylococcus albus P209; their characterization will be reported elsewhere. Here we describe the generation of spontaneous rifampicin-resistant derivatives of KO-1305 and KO-1307 and their initial characterization.

\section{Materials and methods}

S. albus SAM2, a J1074 derivative with deletion of $\varphi \mathrm{C} 31$ pseudo attB site [5], was used throughout the work. The genealogy of $S$. albus strains mentioned in this work is given in Fig. 1. Staph. aureus 209P, Bacillus cereus ATCC19637, Debaryomyces hansenii VKM Y-9 were used in the bioassays as test cultures. We selected Rif variants on GYM agar [6] with $10 \mu \mathrm{g} / \mathrm{mL}$ of rifampicin. Antibiotic resistance and activity assays, sequencing of rpoB alleles were carried out as described in [7]. The other bioassay conditions and media are described in [6]. KO-1408 genome has been sequenced using Illumina approach essentially as described in [8]. The quality control stage the sequence reads was performed by using FastQC (http://www.bioinformatics.babraham.ac.uk/project $\mathrm{s}$ /fastqc). Raw Illumina short reads were qualitytrimmed with Trimmomatic v.0.36 [9]. Sequencing reads were aligned to reference J1074 genome (accession number NC_020990) with Bowtie2 v.2.2.5. SNP and DIP detection was performed by means of ReadXplorer [10]. Only the SNVs and indels different from those found in SAM2 were considered true mutations in KO-1408. BLAST search tools were used to identify genes of interest in the genomes of S. albus J1074 and its derivatives.

\section{Results and discussion}

The spores of $S$. albus KO-1305 and KO1307 strains were spread and incubated on GYM plates supplemented with $10 \mu \mathrm{g} / \mathrm{mL}$ rifampicin, and Rif $^{\mathrm{r}}$ mutants were observed after 3 to 7 days at a frequency of $10^{-7}$ to $10^{-8}$. After three passages under nonselective conditions the resulting mutants (about 80 clones) were again plated onto Rifcontaining agar; all strains exhibited abundant growth. This confirmed the stability of their Rif ${ }^{r}$ phenotype.

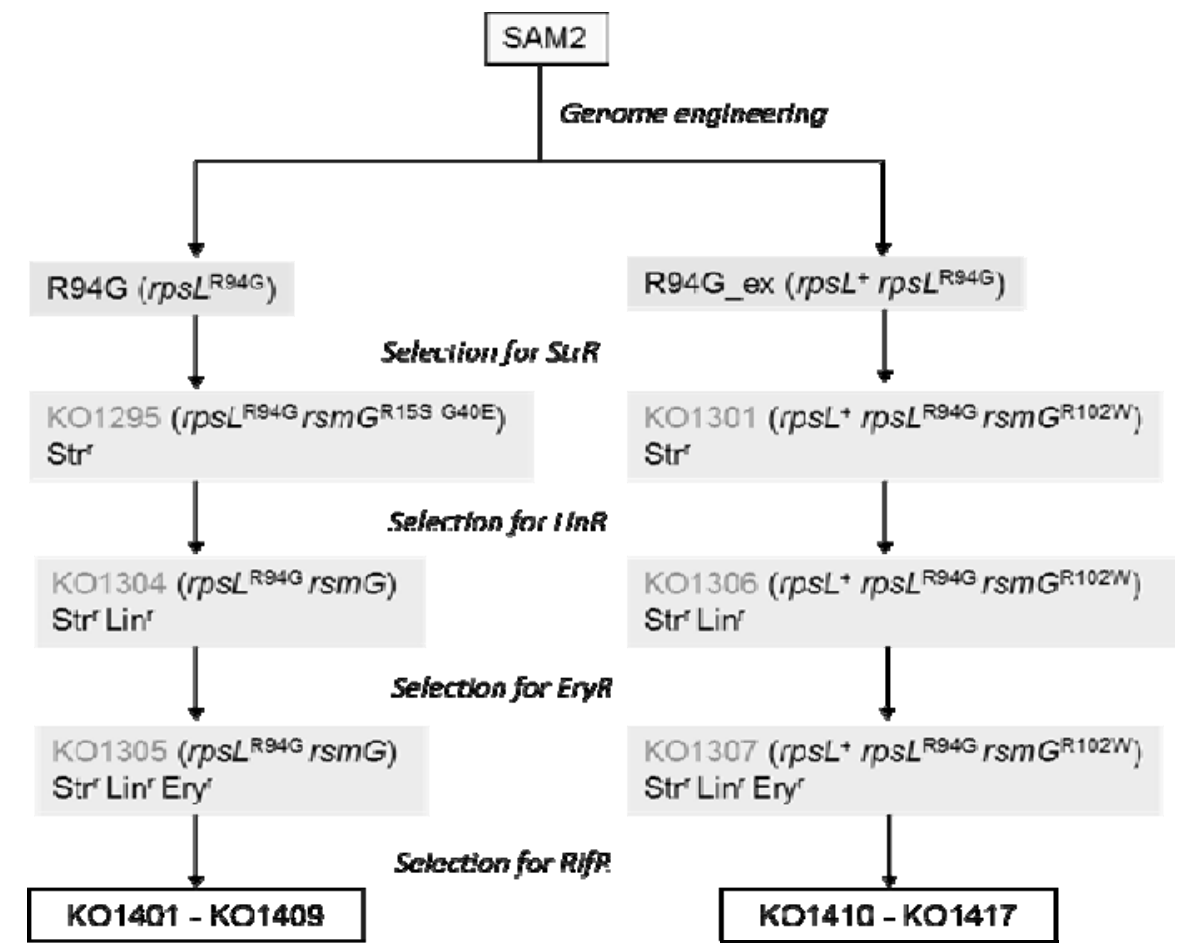

Fig. 1. Scheme of generation of spontaneous Rif mutants KO1401-KO1417 (bottom of the figure). Abbreviations: StrR, resistance to streptomycin; LinR, resistance to lincomycin; EryR, resistance to erythromycin. Other abbreviations and strain names, please see the main text. 
Most often the Rif phenotype arises from mutations in $r p o B$ gene for the RNA polymerase (RNAP) $\beta$-subunit; hence we amplified $r p o B$ (xnr_3712) from our mutants. In all but one cases the rif mutations were located within the so called "rif cluster" of RNAP, encompassing the 422-443 amino acid stretch. The only exception was KO1412, which was revealed to carry missense mutation within $r p o B$ leading to Pro $475 \rightarrow$ Leu substitution. Along with this mutation, two other novel mutations within "rif cluster" were uncovered: Ser433 $\rightarrow$ Trp (KO-1403) and Arg440 $\rightarrow$ Cys (KO-1407). We used spore dilution spot tests to determine Rif resistance level of the mutants; these data, along with sequencing results, are summarized in Table.
We assayed the endogenous antibiotic activity of selected $\mathrm{KO}$ strains using several test cultures (see Materials and methods), GYM and SG2 media, and agar plug tests. Overall, although some merodiploid-based Rif ${ }^{\mathrm{r}}$ strains showed greater activity as compared to their parent (R94G ex) against $S$. aureus 209P, they were less active than KO strains derived from pure R94G rpsL mutant. One notable exception is KO-1412 carrying novel P475L mutation; it showed increased antibiotic activity after 5 days of cultivation in GYM (15-mm halo of 209P growth inhibition), while the parental strain R94G_ex showed almost no activity. Similar trend was observed when GYM-grown agar plugs of the KO strains were assayed against $B$. cereus (Fig. 2).

Table. Mutations and rifampicin resistance levels of various of rpoB mutants isolated from S. albus KO-1305 and KO-1307

\begin{tabular}{|c|c|c|c|c|}
\hline Strain & Mutation in $r p o B$ & $\begin{array}{l}\text { Amino acid } \\
\text { substitution* }\end{array}$ & $\begin{array}{c}\text { Mutant } \\
\text { frequency** }\end{array}$ & $\begin{array}{l}\text { Rif resistance } \\
\quad(\mu \mathrm{g} / \mathrm{mL})\end{array}$ \\
\hline $\mathrm{J} 1074$ & - & - & - & 3 \\
\hline KO-1305 & - & - & - & 3 \\
\hline KO-1401 & $1325 \mathrm{C} \rightarrow \mathrm{T}$ & Ser442 $\rightarrow$ Leu & $1 / 48$ & 30 \\
\hline KO-1402 & $1262 \mathrm{C}-1273 \mathrm{~T} \rightarrow \Delta$ & Q421-F425 $\rightarrow$ L421 & $1 / 48$ & 200 \\
\hline KO-1403 & $1298 \mathrm{G} \rightarrow \mathrm{C}$ & Ser433 $\rightarrow \operatorname{Trp}$ & $1 / 48$ & 10 \\
\hline KO-1404 & $1310 \mathrm{~A} \rightarrow \mathrm{G}$ & His437 $\rightarrow$ Arg & $13 / 48$ & $>200$ \\
\hline KO-1405 & $1309 \mathrm{C} \rightarrow \mathrm{T}$ & His437 $\rightarrow$ Tyr & $15 / 48$ & 200 \\
\hline KO-1406 & $1318 \mathrm{C} \rightarrow \mathrm{A}$ & Arg440 $\rightarrow$ Ser & $1 / 48$ & 20 \\
\hline KO-1407 & $1318 \mathrm{C} \rightarrow \mathrm{T}$ & Arg440 $\rightarrow$ Cys & $5 / 48$ & 25 \\
\hline KO-1408 & $1319 \mathrm{G} \rightarrow \mathrm{A}$ & Arg440 $\rightarrow$ His & $7 / 48$ & 25 \\
\hline KO-1409 & $1271 \mathrm{~A} \rightarrow \mathrm{T}$ & Gln424 $\rightarrow$ Leu & $2 / 48$ & 200 \\
\hline KO-1307 & - & - & - & 3 \\
\hline KO-1410 & $1325 \mathrm{C} \rightarrow \mathrm{T}$ & Ser433 $\rightarrow$ Leu & $1 / 37$ & 25 \\
\hline KO-1411 & $1310 \mathrm{~A} \rightarrow \mathrm{G}$ & His437 $\rightarrow$ Arg & $12 / 37$ & $>200$ \\
\hline KO-1412 & $1451 \mathrm{C} \rightarrow \mathrm{T}$ & Pro $475 \rightarrow$ Leu & $1 / 37$ & 25 \\
\hline KO-1413 & $1309 \mathrm{C} \rightarrow \mathrm{T}$ & His437 $\rightarrow$ Tyr & $16 / 37$ & 200 \\
\hline KO-1414 & $1309 \mathrm{C} \rightarrow \mathrm{G}$ & His437 $\rightarrow$ Asp & $3 / 37$ & 100 \\
\hline KO-1415 & $1271 \mathrm{~A} \rightarrow \mathrm{T}$ & Gln424 $\rightarrow$ Leu & $1 / 37$ & 50 \\
\hline KO-1416 & $1310 \mathrm{~A} \rightarrow \mathrm{C}$ & His $437 \rightarrow$ Pro & $1 / 37$ & $>200$ \\
\hline KO-1417 & $1319 \mathrm{G} \rightarrow \mathrm{A}$ & Arg440 $\rightarrow$ His & $1 / 37$ & 25 \\
\hline
\end{tabular}

Notes: * Highlighted cells correspond to substitutions that are, to the best of our knowledge [2, 7], observed for the first time in Streptomyces; ** Number of mutants out of total Rif clones isolated from a given KO strain. ${ }^{\vee}$ Parental strain for respective Rif ${ }^{r}$ lineages. 

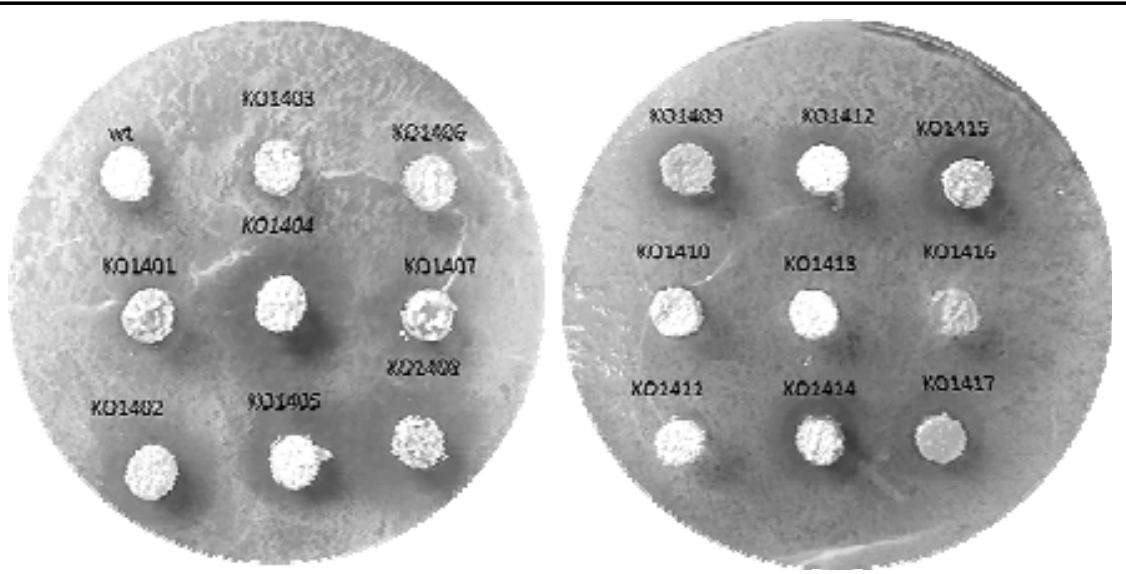

Fig. 2. Halos of B. cereus ATCC19637 growth inhibition around agar plugs of the KO strains cultivated for five days on SG2 agar.

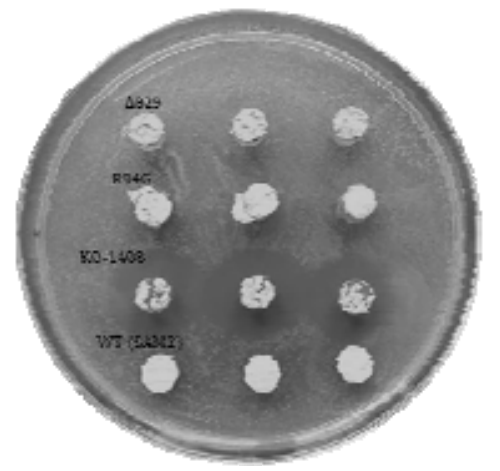

Fig. 3. Halos of B. cereus ATCC19637 growth inhibition around agar plugs of the B29 (paulomycin-deficient derivative of J1074 [11]), R94G, SAM2 and KO-1408 strains. Growth conditions, see Fig. 2. For each strain three agar plugs from different plates were assayed.

No changes in antifungal activity have been observed for the KO strains as compared to parental ones. After a series of bioassays, we have come to conclusion that the mutant KO-1408 (R440H) exhibits the most robust increase in endogenous antibacterial activity, which is evident under different cultivation conditions and against different test cultures. Significantly, this increase appeared to be due to the presence of $r p s L^{\mathrm{R} 94 \mathrm{G}}$ allele in haploid ("pure") state, since isogenic $r p o B^{\mathrm{R} 440 \mathrm{H}}$ mutation in merodiploid $r p s L+r p s L^{\mathrm{R} 94 \mathrm{G}}$ background (KO-1417) did not result in comparable increase in antibiotic activity (Fig. 2).

Next we focused on KO-1408. First, we compared the antibiotic activity of strain lineage leading to KO-1408. The bioassays support the idea that rif mutation leading to $r p o B^{\mathrm{R} 440 \mathrm{H}}$ was a major one that induced antibacterial production by $\mathrm{KO}-$ 1408. Indeed, initial strain R94G (carrying $r p s L^{\mathrm{R} 94 \mathrm{G}}$ allele) had no major effect on antibacterial activity under our cultivation conditions (Fig. 3), and following $\operatorname{Str}^{r}, \operatorname{Lin}^{r}$, Ery $^{r}$ mutations had no effect as well (data not shown).
One caveat is that spontaneous mutants could carry additional as-yet-unknown mutations in their genome which may contribute to the final antibiotic resistance and activity phenotypes. To rule out this scenario for $\mathrm{KO}-1408$, we sequenced its genome as well as genomes of SAM2, R94G, KO-1295, KO1304 and KO-1305. We revealed no new mutations in KO-1408 as compared to KO-1305, except for already known one leading to $r p o B^{\mathrm{R} 440 \mathrm{H}}$ allele. Therefore, the augmented antibiotic potency of KO1408 most likely stems from a combination of known $r p s L^{\mathrm{R} 94 \mathrm{G}}$ and $r p o B^{\mathrm{R} 440 \mathrm{H}}$ mutations.

\section{Conclusions}

S. albus $\mathrm{J} 1074$ attracts interest of academic and industrial researchers as a reliable platform for drug discovery. In this work we describe a set of rifampicin resistant mutants on the basis of multiply antibiotic resistant $S$. albus KO-1305 and KO-1307 strains. Some of the identified Rif mutations within rроB were not previously reported, raising the possibility that $\operatorname{rpoB}$ mutational space leading to Rif resistance is not fully understood despite decades of research. Nevertheless, well-known 
$r p o B^{\mathrm{R} 440 \mathrm{H}}$ turned out to be the most effective in terms of enhancement of secondary metabolism of $S$. albus. It remains to be studied the production of what compounds is activated in KO-1408 and other strains; and whether these mutants will support the increased production of compounds directed by heterologous BGCs. Experiments are underway in our laboratories to address these questions.

This work was supported by grants F60-2015 from State Fund for Fundamental Research of Ukraine and BG-80F from Ministry of Education and Science of Ukraine (both to B.O.). C. Olano (Oviedo University) is thanked for gift of $\triangle B 29$ S. albus strain.

\section{References}

1. Myronovskyi M., Luzhetskyy A. Heterologous production of small molecules in the optimized Streptomyces hosts. Nat. Prod. Rep. 2019. Vol. 36. P. 1281-1294. doi: 10.1039/c9np00023b.

2. Ochi K. Insights into microbial cryptic gene activation and strain improvement: principle, application and technical aspects. J. Antibiot. 2017. Vol. 70. P. 25-40. doi: 10.1038/ja.2016.82.

3. Lopatniuk M., Myronovskyi M., Nottebrock A., Busche T., Kalinowski J., Ostash B., Fedorenko V., Luzhetskyy A. Effect of "ribosome engineering" on the transcription level and production of $S$. albus indigenous secondary metabolites. Appl. Microbiol. Biotechnol. 2019. Vol. 103. P. 7097-7110. doi: 10.1007/s00253-019-10005-y.

4. Siegl T., Luzhetskyy A. Actinomycetes genome engineering approaches. Antonie Van Leeuwenhoek. 2012. Vol. 102. P. 503516.

5. Bilyk B., Luzhetskyy A. Unusual site-specific DNA integration into the highly active pseudo-attB of the Streptomyces albus J1074 genome. Appl. Microbiol. Biotechnol. 2014. Vol. 98. P. 5095-5104. doi: 10.1007/s00253-014-5605-y.

6. Koshla O., Lopatniuk M., Rokytskyy I., Yushchuk O., Dacyuk Y., Fedorenko V., Luzhetskyy A., Ostash B. Properties of

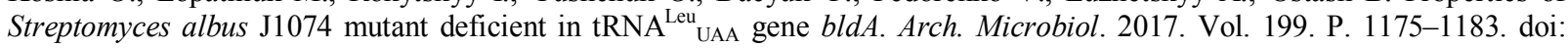
10.1007/s00203-017-1389-7.

7. Tanaka Y., Kasahara K., Hirose Y., Murakami K., Kugimiya R., Ochi K. Activation and products of the cryptic secondary metabolite biosynthetic gene clusters by rifampin resistance (rpoB) mutations in actinomycetes. J. Bacteriol. 2013. Vol. 195. P. 2959-2970. doi: 10.1128/JB.00147-13.

8. Yushchuk O., Ostash I., Vlasiuk I., Gren T., Luzhetskyy A., Kalinowski J., Fedorenko V., Ostash B. Heterologous AdpA transcription factors enhance landomycin production in Streptomyces cyanogenus S136 under a broad range of growth conditions. Appl. Microbiol. Biotechnol. 2018. Vol. 102. P. 8419-8428. doi: 10.1007/s00253-018-9249-1.

9. Bolger A.M., Lohse M., Usadel B. Trimmomatic: a flexible trimmer for Illumina sequence data. Bioinformatics. 2014. Vol. 30. P. 2114-2120. doi: 10.1093/bioinformatics/btu170.

10. Hilker R., Stadermann K. B., Doppmeier D., Kalinowski J., Stoye, J. Straube, J., et al. ReadXplorer - visualization and analysis of mapped sequences. Bioinformatics. 2014. Vol. 30. P. 2247-2254. doi: 10.1093/bioinformatics/btu205.

11. Olano C., Garcнa I., Gonzбlez A., et al. Activation and identification of five clusters for secondary metabolites in Streptomyces albus J1074. Microb Biotechnol. 2014. Vol. 7. P. 242-256. doi:10.1111/1751-7915.12116.

ОСТАШ Б.О. ${ }^{1}$ МІСАКІ Ю. ${ }^{2}$, ДОЛЯ Б.С. ${ }^{1}$, ХАРАТОН Я.І. ${ }^{1}$, БУШЕ Т. ${ }^{3}$, ЛУЖЕЦЬКИЙ А.М. ${ }^{4}$, КАЛІНОВСКІ Й. ${ }^{3}$, ОЧІ К. ${ }^{2}$, ФЕДОРЕНКО В.О. ${ }^{1}$

${ }^{I}$ Львівський національний університет ім. I. Франка,

Україна, 79005, м. Львів, вул. Грушевського, 4

${ }^{2}$ Технологічний інститут Хірошіми,

Японія, Хірошіма

${ }^{3}$ Центр Біотехнології , університет Білефельда,

ФРН, Білефельд

${ }^{4}$ Університет Саарланду,

ФРН, Саарбрюкен

\section{КОНСТРУЮВАННЯ І ВИХІДНА ХАРАКТЕРИСТИКА КОЛЕКЦІї СПОНТАННИХ МУТАНТІВ STREPTOMYCES ALBUS Ј1074 СТІЙКИХ ДО РИФАМПІЦИНУ}

Mema. Streptomyces albus J1074 - одна із найпопулярніших стрептоміцетних платформ для гетерологічної експресії кластерів генів біосинтезу природних сполук. Становить інтерес у дослідженнях, які б вели до підвищених кількостей продукції відповідних сполук. Уведення певних типів мутацій стійкості до антибіотиків - доведений шлях селекції штамів Streptomyces. Наприклад, селекція за стійкістю до рифампіцину веде до зростання антибіотичної активності. У цій роботі ми використали наявні лінії антибіотикорезистентні лінії S. albus для отримання рифампіцин-стійких варіантів (Rif') та їхнього вивчення. Memodи. Застосовано мікробіологічні та молекулярно-генетичні підходи для селекції Rif ${ }^{x}$ мутантів та вивчення їхніх властивостей. Результати. Виділено 85 стабільних Rif клонів, чия резистентність була у межах 10-200 мкг/мл. Секвенування виявило широкий спектр міссенс-мутацій у межах гена $r p o B$. Біотести виявили сильне зростання ендогенної антибіотичної активності деяких Rif мутантів. Висновки. Селекція за стійкістю до рифампіцину перспективний спосіб селекції високопродуктивних штамів S. albus.

Ключові слова: Streptomyces albus J1074, стійкість до антибіотиків, рифампіцин. 